\title{
Alternative Splicing of Human Telomerase Reverse Transcriptase May Not Be Involved in Telomerase Regulation During all-trans-Retinoic Acid-Induced HL-60 Cell Differentiation
}

\author{
Wei-Jun Liu ${ }^{1, \#}$, Yong-Wei Zhang ${ }^{1, \#}$, Zhi-Xiang Zhang ${ }^{1}$, and Jian Ding ${ }^{1, *}$ \\ ${ }^{I}$ Division of Anti-tumor Pharmacology, State Key Laboratory of Drug Research, Shanghai Institute of Materia Medica, \\ Shanghai Institutes for Biological Sciences, Chinese Academy of Sciences, Shanghai 201203, China
}

Received December 22, 2003; Accepted August 4, 2004

\begin{abstract}
Alternative splicing of the human telomerase reverse transcriptase subunit (hTERT) suppresses telomerase activity during the development of human fetal kidney cells into mature cells. Tumor cell differentiation is the process of turning abnormal tumor cells into 'normal' cells accompanied by down-regulation of telomerase activity. However, the precise mechanism of the regulation of telomerase activity in differentiated cells is not fully understood. In this study, we observed the role of alternative splicing of hTERT in the regulation of telomerase activity in all-trans-retinoic acid (ATRA)-induced, differentiated HL-60 cells. ATRA-induced downregulation of telomerase activity in differentiated HL-60 cells was associated with a decrease in hTERT and an increase in human telomerase-associated protein-1 (hTP1) transcription. Expression of full length variant hTERT $\alpha^{+} \beta^{+}$mRNA decreased in a dose- and time-dependent manner. The drop of hTERT $\beta^{-}$mRNA was time-dependent. hTERT $\alpha^{-}$and hTERT $\alpha^{-} \beta^{-}$ mRNA were reduced dramatically after ATRA treatment. In the dose-effect study, hTERT $\alpha^{+} \beta^{+}$ and hTERT $\beta^{-}$maintained a relatively stable ratio when telomerase activity decreased largely from treatment with 1 to $5 \mu \mathrm{M}$ ATRA. Although the splicing pattern of hTERT mRNA was altered in time-effect research, the change was not related to the ATRA-treated decline of telomerase activity. The expression of alternative splicing variants of hTERT also decreased at the protein level. All these results suggested that alternative splicing of hTERT mRNA may not contribute to the suppression of telomerase activity during ATRA-induced HL-60 leukemia cell differentiation.
\end{abstract}

Keywords: telomerase, human telomerase reverse transcriptase, alternative splicing, differentiation, all-trans-retinoic acid

\section{Introduction}

Human telomerase is a ribonucleoprotein enzyme that maintains telomere length by catalyzing the addition of hexameric repeats (TTAGGG) $)_{\mathrm{n}}$ to telomeres $(1,2)$. Telomerase activity can be detected in most cells that have an increased ability to replicate, such as cancer cells, germ-line cells and certain stem cells $(3-6)$, but not in somatic cells $(7,8)$, suggesting that telomerase plays a crucial role in cell proliferation and cellular

\footnotetext{
\# These authors contributed equally to this work.

*Corresponding author. FAX: +86-21-50806722

E-mail: jding@mail.shcnc.ac.cn
}

immortality and carcinogensis. Moreover, forced expression of telomerase activity in telomerase-negative cells resulted in immortalization (9) or even direct conversion to tumor cells (10). Telomerase has thus been proposed as a hopeful target for anticancer therapies. It has been demonstrated that telomerase activity is significantly suppressed in differentiated HL-60 cells induced by various differentiating agents (11-14) including all-trans-retinoic acid (ATRA), which has been widely used clinically as a chemopreventive and differentiation-inducer (15). Yamada et al. reported that down-regulation of telomerase activity is an early event of cellular differentiation without apparent telomeric DNA damage (16). However, the 
precise mechanism of regulating telomerase activity in ATRA-induced, differentiated cells is not understood.

The hTERT transcript contains at least six alternate splicing sites, including two deletions $(\alpha$ and $\beta$ ) and four insertions of intron sequences into hTERT mRNA $(17,18)$. Different sets of hTERT variants were also detected in some normal ovarian tissues and myometrial leiomyomas lacking telomerase activity (19). It has been also found that the hTERT transcript is alternatively spliced in cultured cancer cells with high telomerase activity. When hTERT $\alpha^{-}$was introduced into telomerase-positive tumor cells, it could inhibit telomerase activity and caused telomere shortening and eventually cell death $(20,21)$. These results suggest that alternative splicing of hTERT may effect a decrease in telomerase activity in cells under certain conditions such as fetation and tumorigenesis.

Although there is some comparability between fetal development and cancer cell differentiation, it is still unknown whether hTERT transcript splicing is involved in the regulation of telomerase activity during the differentiation of tumor cells. The present study aims to investigate the role of alternative splicing of hTERT in telomerase regulation in ATRA-induced, differentiated HL-60 cells and provide a basis for testing if the alternative splicing of hTERT can be served as one target of anticancer therapy.

\section{Materials and Methods}

\section{Cell culture}

Human acute promyelocytic leukemia HL-60 cells were cultured in RPMI-1640 medium supplemented with $10 \%(\mathrm{v} / \mathrm{v})$ heat-inactivated fetal bovine serum, penicillin $(100 \mathrm{IU} / \mathrm{ml})$, streptomycin $(100 \mu \mathrm{g} / \mathrm{ml})$, and $2 \mathrm{mM}$ L-glutamine at $37^{\circ} \mathrm{C}$ in a humidified atmosphere containing $5 \% \mathrm{CO}_{2}$.

\section{Reagents}

ATRA was supplied by the Sixth Pharmaceutical Company of Shanghai (China). All PCR primers used in this study were synthesized by Sangon Co. (Shanghai, China). M-MLV reverse transcriptase (RT) and Random Hexamers were purchased from Promega (Madison, WI, USA). RPMI-1640 medium and Trizol reagent were purchased from Gibco-BRL (Grand Island, NY, USA).

\section{Induction of differentiation}

Differentiation was assessed by morphological changes identified by Giemsa staining, and changes in CD11b antigen expression were determined by flow cytometry. Briefly, $1 \times 10^{6}$ HL-60 cells were treated with $10 \mu \mathrm{M}$ ATRA for $1-3$ days. At the time indicated, cells were collected and subjected to flow cytometry or morphological examination of differentiation. Experiments were repeated three times.

\section{Telomerase activity assay}

Telomerase activity was assayed by the TRAP method (22). In brief, telomerase was extracted with CHAPS (3-[(3-cholamidopropyl)dimethyl ammonio]-1propane-sulphonate)-based telomerase lysis buffer [10 mM Tris- $\mathrm{HCl}$ ( $\mathrm{pH} 7.5), 1 \mathrm{mM} \mathrm{MgCl} 2,1 \mathrm{mM}$ EGTA, $0.1 \mathrm{mM}$ PMSF, $5 \mathrm{mM} \quad \beta$-ME, $0.5 \%$ CHAPS, $10 \%$ glycerol]. Protein extracts were diluted appropriately, and an aliquot of $0.5-\mu \mathrm{g}$ protein was incubated with $0.1 \mu \mathrm{g}$ TS primer (5'-AAT CCG TCG AGC AGA GTT$\left.3^{\prime}\right)$ for $25 \mathrm{~min}$ at $30^{\circ} \mathrm{C}$ in the following reaction mixture: $20 \mathrm{mM}$ Tris- $\mathrm{HCl}$ (pH 8.3), $1.5 \mathrm{mM} \mathrm{MgCl}_{2}, 63 \mathrm{mM} \mathrm{KCl}$, $0.005 \%$ Tween-20, $1 \mathrm{mM}$ EGTA, and $50 \mu \mathrm{M}$ of each deoxynucleoside triphosphates (dNTPs). Following elongation of the TS primer by telomerase, the mixture was incubated at $85^{\circ} \mathrm{C}$ for 5 min before the addition of $3 \mathrm{U}$ of Taq polymerase and $0.1 \mu \mathrm{g} \mathrm{ACX}$ return primer (5'-GCG CGG[CTT ACC $]_{3}$ CTA ACC-3'], 0.01 amol internal control template TSNT(5'-AAT CCG TCG AGC AGA GTT AAA AGG CCG AGA AGC GAT-3'), $0.1 \mu \mathrm{g}$ internal control return primer NT(5'-ATC GCT TCT CGG CCT TTT-3'), and the elongated products were then amplified by PCR $\left(29\right.$ PCR cycles at $94^{\circ} \mathrm{C}$ $30 \mathrm{~s}, 60^{\circ} \mathrm{C} 30 \mathrm{~s}$ ). The PCR products were examined by electrophoresis on a $10 \%$ non-denatured polyacrylamide gel in $1 \times$ TBE and stained with SYBR green I Nucleic Acid Gel Stain (FMC, Rockland, ME, USA) for $15 \mathrm{~min}$. Relative telomerase activities were quantitated using the Gel Document System GDS8000 (UVP, Cambridge, UK).

\section{RT-PCR analysis of telomerase subunits}

Total RNA was isolated from HL-60 cells using Trizol. The first-strand cDNA was synthesized using M-MLV RT (Promega). The cDNA samples were amplified in $50 \mu \mathrm{L}$ of reaction mixture containing $200 \mu \mathrm{M}$ each of the four dNTPs, 3 units of Taq DNA polymerase (Promega), and $0.1 \mu \mathrm{M}$ of specific primers. The primers used in this study are listed in Table 1. Amplification of alternatively spliced hTERT cDNA was performed with initial heating at $94^{\circ} \mathrm{C}$ for $90 \mathrm{~s}$, followed by 35 cycles of $95^{\circ} \mathrm{C}$ for $25 \mathrm{~s}, 68^{\circ} \mathrm{C}$ for $50 \mathrm{~s}$, and $72^{\circ} \mathrm{C}$ for $50 \mathrm{~s}$. Other cDNA samples were amplified with the following sequence for 28 cycles: $94^{\circ} \mathrm{C}$ for $30 \mathrm{~s}, 60^{\circ} \mathrm{C}$ for $30 \mathrm{~s}$, and $72^{\circ} \mathrm{C}$ for $30 \mathrm{~s}$. The amplified alternatively spliced hTERT product was separated by electrophoresis on 10\% polyacrylamide-urea gel and other PCR products were separated on $2 \%$ agarose gel. Gels were stained with ethidium bromide and photo- 
Table 1. The PCR primers used in this study

\begin{tabular}{ll}
\hline PCR products & Primer sequences \\
\hline hTERT & 5'-CGG AAG AGT GTC TGG AGC AA-3' (sense) \\
& 5'-GGA TGA AGC GGA GTC TGG A -3' (antisense) \\
hTR & 5'-TCT AAC CCT AAC TGA GAA GGG CGT AG-3' (sense) \\
& 5'-GTT TGC TCT AGA ATG AAC GGT GGA AG-3' (antisense) \\
hTP1 & 5'-TCA AGC CAA ACC TGA ATC TGA G-3' (sense) \\
& 5'-CCC GAG TGA AAA TCT TTC TAC GC-3' (antisense) \\
Splicing variants of hTERT & 5'-GCC TGA GCT GTA CTT TGT CAA-3' (sense) \\
& 5'-CGC AAA CAG CTT GTT CTC CAT GTC-3' (antisense) \\
GAPDH & 5'-CCA TGG AGA AGG CTG GGG-3' (sense) \\
& 5'-CAA AGT TGT CAT GGA TGA CC-3' (antisense) \\
\hline
\end{tabular}

graphed using the Gel Document System GDS8000 (UVP).

\section{Western blot}

Cellular proteins of equal amount $(50 \mu \mathrm{g})$ derived from control and ATRA-treated HL-60 cells were separated on $10 \%$ SDS-polyacrylamide gels and transferred to nitrocellulose membranes. After blocking with block solution $(5 \%$ milk, $0.1 \%$ Tween- $20,10 \mathrm{mM}$ Tris- $\mathrm{HCl}$ $\mathrm{pH} 7.5,150 \mathrm{mM} \mathrm{NaCl}$ ) for $2 \mathrm{~h}$, the membrane was exposed to a mouse anti-hTERT polyclonal antibody (23) with a 1:1000 dilution at $4^{\circ} \mathrm{C}$ overnight. The membrane was subsequently incubated with a horseradish peroxidase-conjugated secondary antibody (1:1000) for $1 \mathrm{~h}$ at room temperature. Bands were developed using the SuperSignal West Pico Kit (Pierce, Rockford, IL, USA). As a control, the bottom portion of the membrane was removed and probed with goat polyclonal antibody (C-11; Santa Cruz Biotechnology, Santa Cruz, CA, USA) recognizing actin.

\section{Results}

\section{Differentiation of HL-60 cells induced by ATRA}

HL-60 cells were induced to differentiate to a granulocytic or monocytic phenotype by treatment with $10 \mu \mathrm{M}$ ATRA. The morphological changes to HL-60 cells were observed by Giemsa staining. After treatment with ATRA for $24 \mathrm{~h}$, the nucleus of some HL- 60 cells became indented; and after treatment for $48 \mathrm{~h}$, nuclear segmentation was visible. Prolonged incubation for $72 \mathrm{~h}$ with ATRA resulted in more nuclei becoming constricted, indented, or segmented and a decrease in the cell size (Fig. 1A). Expression of the CD11b antigen, which is the specific marker for HL-60 cell differentiation towards granulocytes and monocytes, was also detected by flow cytometry. Its expression rate increased with exposure time, and the expression rate $(22.7 \pm$ $1.73 \%$ ) of the 72 -h group was about 5 -fold higher than that of the control group $(4.8 \pm 0.55 \%)$ (Fig. 1B). These results indicate that treatment with ATRA at $10 \mu \mathrm{M}$ for $72 \mathrm{~h}$ could induce HL-60 cell differentiation. This incubation period was used for subsequent studies.

Down-regulation of telomerase activity by ATRA in a time- and dose-dependent manner

In the process of differentiation of HL-60 cells induced by ATRA, down-regulation of telomerase activity was observed in a time- and dose-dependent manner. Telomerase activity in HL-60 cells began to decrease after 12-h exposure to $10 \mu \mathrm{M}$ ATRA and decreased sharply after 48-h exposure. Telomerase activity was barely detectable when the cells were treated with ATRA for $72 \mathrm{~h}$. The relative telomerase activity was $85.66 \%, 82.14 \%, 37.96 \%$, and $8.06 \%$ of the control for $12,24,48$, and $72 \mathrm{~h}$ treatments, respectively (Fig. 2A). After 72-h exposure of HL-60 cells to 1, 2, 5, and $10 \mu \mathrm{M}$ ATRA, telomerase activity was $89.43 \%, 44.14 \%, 5.72 \%$, and $1.61 \%$ of that in the control cells, respectively (Fig. 2B).

Expression of telomerase subunits at mRNA level in ATRA-induced differentiated HL-60 cells

To investigate the regulatory mechanisms involved in ATRA-induced down-regulation of telomerase activity, expression of three telomerase subunits (hTR, hTERT, and hTP1) was examined at the mRNA level using RT-PCR. hTERT expression was initially measured using primers for a region of the transcript upstream of the reverse transcriptase domain. Among the three subunits, the change in hTERT expression was the most significant. It began to decrease after treatment with $1 \mu \mathrm{M}$ ATRA and declined to a very low level following treatment with $10 \mu \mathrm{M}$ ATRA for $72 \mathrm{~h}$. In contrast, 

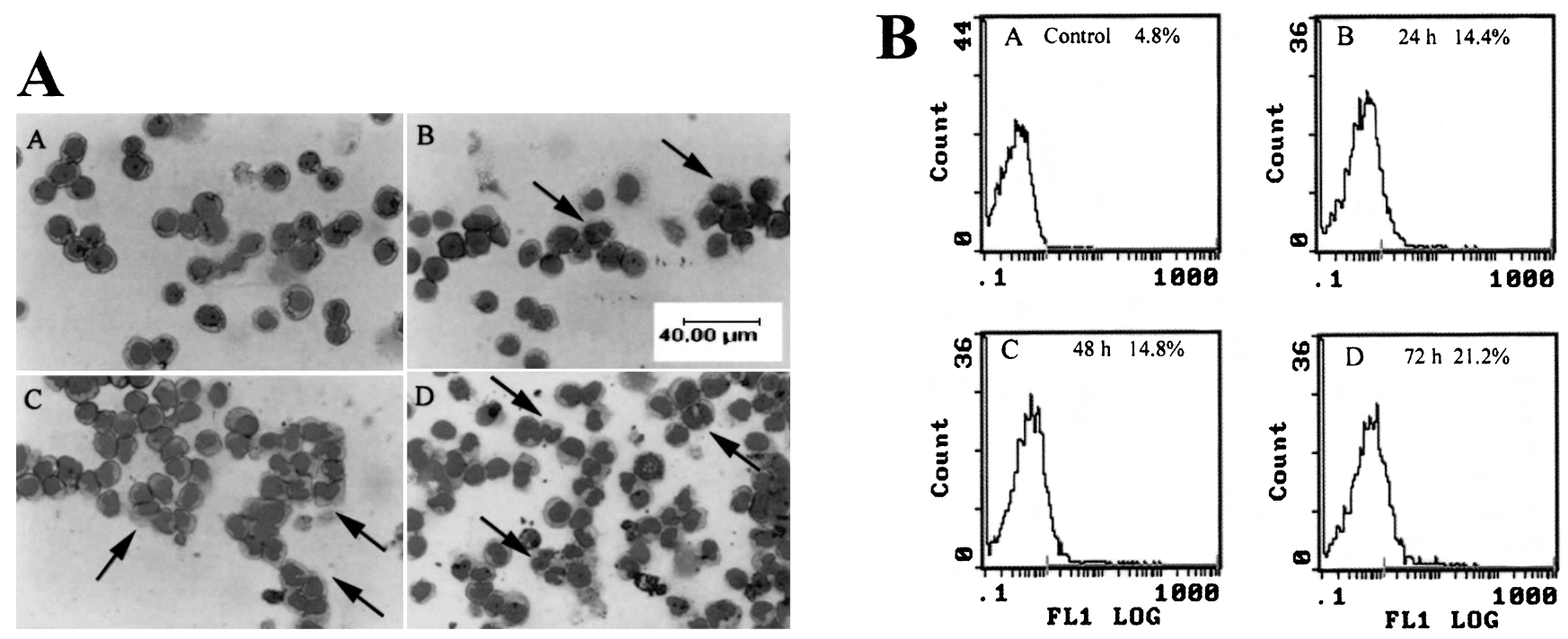

Fig. 1. ATRA-induced HL-60 cell differentiation. A: Representative morphological changes of HL-60 cells untreated (A) or treated with ATRA $(10 \mu \mathrm{M})$ for $24 \mathrm{~h}(\mathrm{~B}), 48 \mathrm{~h}(\mathrm{C})$, and $72 \mathrm{~h}(\mathrm{D})$, respectively. The arrows indicate differentiated cells. Magnification $\times 400$. B: Expression of CD11b differentiated antigen in HL-60 cells increased depending on time, untreated (A) or treated with ATRA $(10 \mu \mathrm{M})$ for $24 \mathrm{~h}(\mathrm{~B}), 48 \mathrm{~h}(\mathrm{C})$, and $72 \mathrm{~h}(\mathrm{D})$, respectively. The representative results of three independent experiments are shown.

hTP1 mRNA expression increased in a dose-dependent manner. With treatment with $1,5,10 \mu \mathrm{M}$ ATRA, hTP1 mRNA expression was $136 \%, 199 \%$, and $300 \%$ of the control, respectively. There was no obvious change in hTR mRNA expression after ATRA treatment (Fig. 3).

Expression of splicing variants of hTERT in ATRAinduced, differentiated HL-60 cells

To examine whether the splicing of hTERT was involved in the regulation of telomerase activity in ATRA-induced HL-60 cell differentiation, expression of alternatively spliced hTERT with the full length functional and the defective RT region was examined using primers spanning the RT region of hTERT. This region contains potential $\alpha$ and $\beta$ splicing sites. The hTERT mRNA with a full length RT region was identified as hTERT $\alpha^{+} \beta^{+}$. mRNAs containing a defective RT region from alternative splicing were identified as hTERT $\alpha^{-}$, hTERT $\beta^{-}$, and hTERT $\alpha^{-} \beta^{-}$, representative of $\alpha$ deletion, $\beta$ deletion, and both deletions, respectively. Analysis of mRNA showed that all four alternative splicing forms of hTERT transcripts were observed in untreated HL-60 cells. In the dose-effect study, expression of the full-length hTERT $\alpha^{+} \beta^{+}$mRNA decreased significantly in a dose-dependent manner after ATRA treatment. hTERT $\alpha^{-}$mRNA decreased dramatically upon treatment of ATRA and became undetectable on $1 \mu \mathrm{M}$ ATRA. hTERT $\alpha^{-} \beta^{-}$mRNA were also reduced to a very low level with $1 \mu \mathrm{M}$ ATRA treatment and almost invisible at $5 \mu \mathrm{M}$ ATRA $(72 \mathrm{~h})$. hTERT $\beta^{-}$was also downregulated quite a bit by $1 \mu \mathrm{M}$ ATRA and then a relatively steady expression remained with the treatment of 5 or $10 \mu \mathrm{M}$ ATRA (Fig. 4A). To analyze the distribution of alternative splicing variants of hTERT, each variant's percent of the control total hTERT mRNA was quantitated and summarized. This analysis showed a relative stable ratio of hTERT $\alpha^{+} \beta^{+}$ and hTERT $\beta^{-}$when telomerase activity decreased dramatically from 1 to $5 \mu \mathrm{M}$ ATRA treatment (Table 2).

In time-effect research, the full-length hTERT $\alpha^{+} \beta^{+}$ mRNA was decreased to a rather low level when cells were treated with $10 \mu \mathrm{M}$ ATRA for $24 \mathrm{~h}$ (Fig. 4C). hTERT $\alpha^{-}$and hTERT $\alpha^{-} \beta^{-}$mRNA could not be detected at that time. hTERT $\beta^{-}$mRNA decreased in a time-dependent manner. The variant's distribution assay demonstrated the pattern of hTERT splicing was altered. However, the change of hTERT mRNA splicing was unconcerned with ATRA-treated decline of telomerase activity (Table 3 ).

These results indicated that ATRA decreased the expression of both the functional and three non-functional hTERT mRNAs, suggesting that hTERT splicing might not play a role in ATRA-induced down-regulation of telomerase activity in HL-60 cells.

To further verify the results at the mRNA level, we examined the expression of these variants at the protein level. It is unclear at present whether all alternative splicing variants of hTERT are translated or not, and also, there is no available antibody that can recognize one certain variant specifically. In order not to miss the 
A
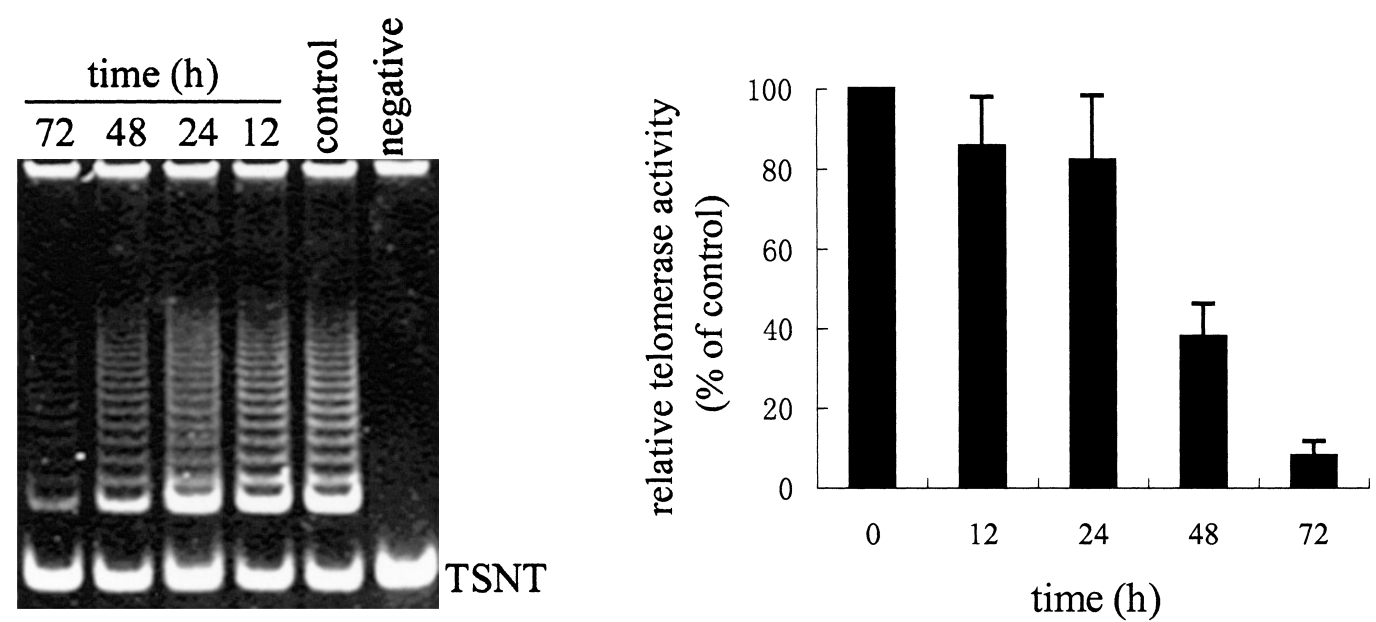

B
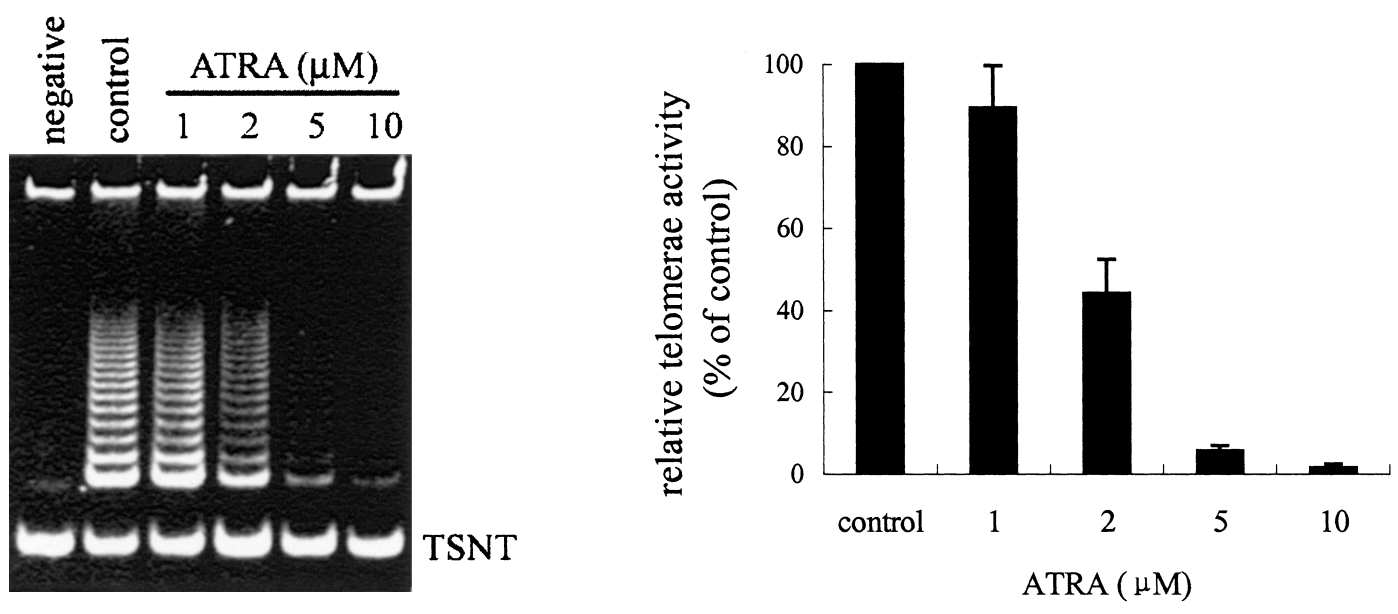

Fig. 2. ATRA-induced down-regulation of telomerase activity in HL-60 cells in a time (A)- and dose (B)-dependent manner. ATRA, $10 \mu \mathrm{M}(\mathrm{A})$; time, $72 \mathrm{~h}$ (B). Results are from two similar experiments.

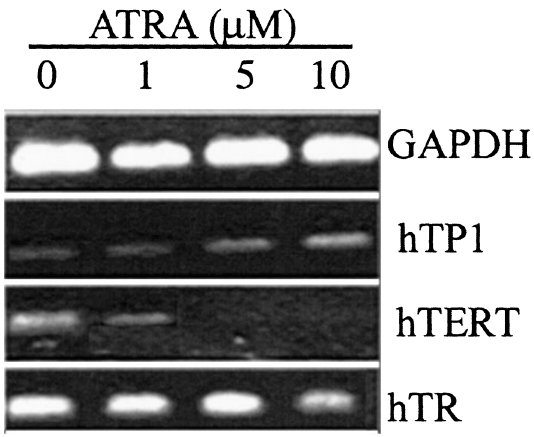

Fig. 3. Expression of telomerase subunits in HL-60 cells treated with ATRA at concentrations of $0,1,5$, and $10 \mu \mathrm{M}$ for $72 \mathrm{~h}$, respectively. Results shown here are from one representative experiment.

change of every variant at the protein expression level, a versatile antibody that has the ability to detect all possible translation products of hTERT mRNA should be used. In this study, we applied a polyclonal antibody against the translation product of human hTERT gene segment from the 1784 to $2369 \mathrm{bp}$ (23). Since all splicing variants comprise some or the entire segment, this antibody can theoretically recognize them. As shown in Fig. 4B, two bands with molecular weight $>116 \mathrm{KDa}$ and approx. $100 \mathrm{kDa}$ were detected. This result is similar with the previous report (23). The $>116 \mathrm{kDa}$ band was the protein containing the full length of hTERT, because the molecular weight of the hTERT protein is $125 \mathrm{kDa}$. The $110 \mathrm{kDa}$ protein may be one of the spliced variants of hTERT, although it is not clear which variant it is. Consistent with expression at the mRNA level, ATRA down-regulated the expression of both hTERT proteins in a dose-dependent manner, while the expression of the internal control protein actin was not affected. 

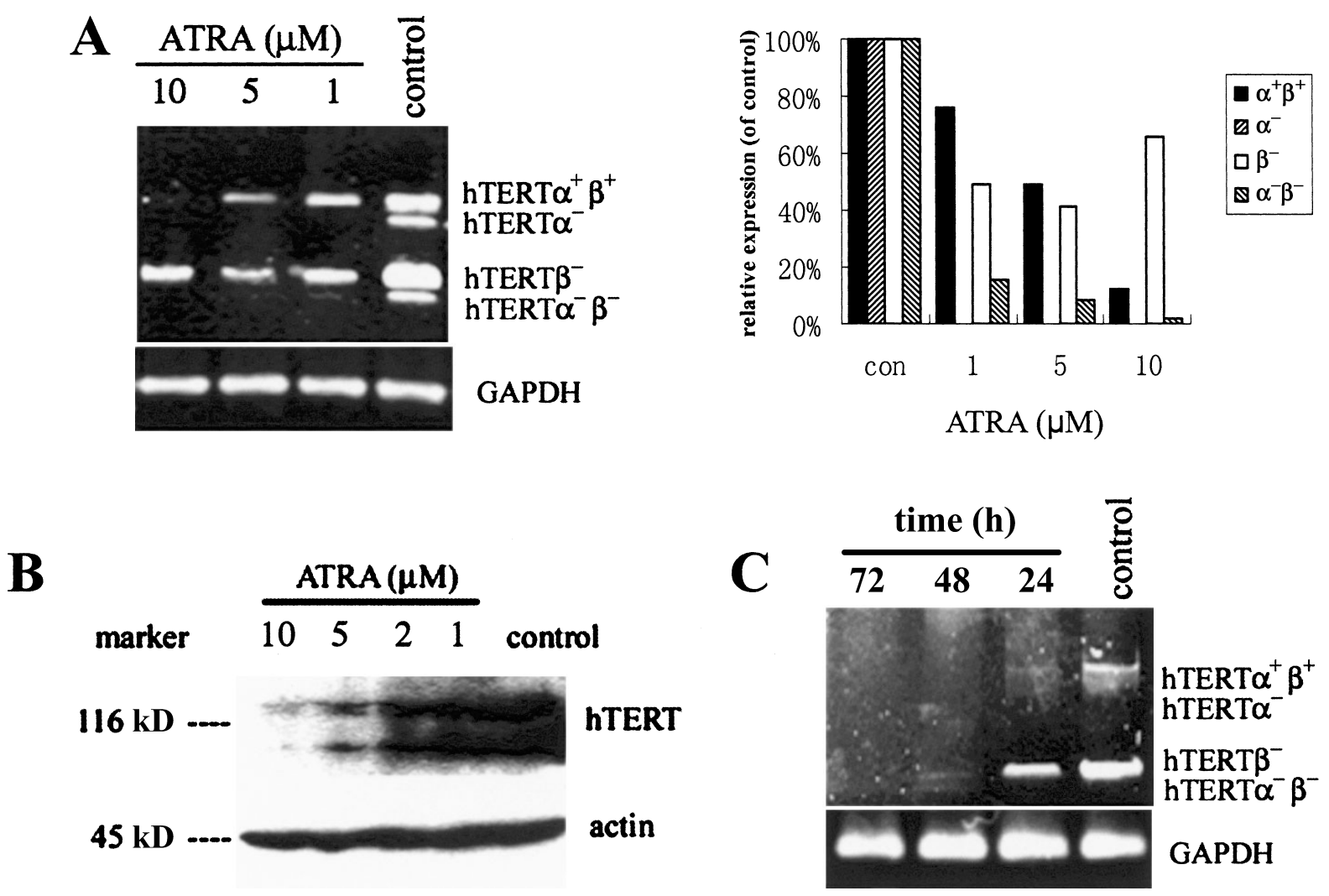

Fig. 4. Expression of alternatively splicing variants of hTERT at the mRNA (A) and protein (B) level in ATRA-treated HL-60 cells. Each result is from one representative experiment. A: HL-60 cells treated with ATRA at concentrations of $0,1,5$, and $10 \mu \mathrm{M}$ for $72 \mathrm{~h}$, respectively; C: HL-60 cells treated with $10 \mu \mathrm{M}$ ATRA for $0,24,48$, and $72 \mathrm{~h}$, respectively.

Table 2. The distribution of hTERT splicing variants and relative telomerase activity at different ATRA concentration $(72 \mathrm{~h})$

\begin{tabular}{lrrrr}
\hline Splicing variants & Control* & $1 \mu \mathrm{M}$ & $5 \mu \mathrm{M}$ & $10 \mu \mathrm{M}$ \\
\hline hTERT $\alpha^{+} \beta^{+}$ & $35.70 \%$ & $27.23 \%$ & $17.5 \%$ & $4.39 \%$ \\
hTERT $\alpha^{-}$ & $16.70 \%$ & $0 \%$ & $0 \%$ & $0 \%$ \\
hTERT $\alpha^{-} \beta^{-}$ & $14 \%$ & $2.15 \%$ & $1.15 \%$ & $28 \%$ \\
hTERT $\beta^{-}$ & $33.60 \%$ & $16.4 \%$ & $13.9 \%$ & $22.0 \%$ \\
relative telomerase activity & $100 \%$ & $89.43 \%$ & $5.72 \%$ & $1.61 \%$ \\
\hline
\end{tabular}

*Control, cell not treated by ATRA; Percentage of each variant $(\%)=($ Each variant in one sample / Total hTERT mRNA of Control cells) $\times 100 \%$.

Table 3. The distribution of hTERT splicing variants and relative telomerase activity at different time (ATRA, $10 \mu \mathrm{M})$

\begin{tabular}{lrrrr}
\hline Splicing variants & Control* & $24 \mathrm{~h}$ & $48 \mathrm{~h}$ & $72 \mathrm{~h}$ \\
\hline hTERT $\alpha^{+} \beta^{+}$ & $29.80 \%$ & $4.2 \%$ & $2.71 \%$ & $2.38 \%$ \\
hTERT $\alpha^{-}$ & $4.10 \%$ & $0 \%$ & $0 \%$ & $0 \%$ \\
hTERT $\alpha^{-} \beta^{-}$ & $2.50 \%$ & $0 \%$ & $0 \%$ & $0 \%$ \\
hTERT $\beta^{-}$ & $63.60 \%$ & $38.6 \%$ & $7.03 \%$ & $6.8 \%$ \\
relative telomerase activity & $100 \%$ & $82.14 \%$ & $37.96 \%$ & $8.06 \%$ \\
\hline
\end{tabular}

*Control, cell not treated by ATRA; Percentage of each variant $(\%)=($ Each variant in one sample $/$ Total hTERT mRNA of Control cells) $\times 100 \%$. 


\section{Discussion}

ATRA is a well-known acute promyelocytic leukaemia (APL) cell differentiation inducer, and recently it is reported that telomerase activity is downregulated during the course of differentiation. Sharma et al. (11) demonstrated that differentiation-inducing agents do not directly inhibit telomerase activity and speculated that cellular differentiation induced by them was associated with repression of transcription of one or more genes encoding either the RNA or the protein subunits of telomerase. The present and other studies confirmed this hypothesis $(11-14,16)$. There was a drastic decrease of hTERT mRNA in ATRA-induced, differentiated HL-60 cells. Repression of hTERT transcription is a common event after treatment with differentiation inducers, independent of the drug used. Recent data suggested that the hTERT promoter E-box switching from Myc/Max to Mad1/Max binding during differentiation might be responsible for this transcriptional reduction (24). Our results showed that the telomerase activity had decreased to nearly $5 \%$ that of untreated cells, while the expression of hTERT $\alpha^{+} \beta^{+}$mRNA decreased to $50 \%$ of the control level, which seemed to indicate that hTERT transcription did not parallel telomerase activity. The inconsistency of hTERT gene expression and telomerase activity was also observed in other studies $(25-27)$. It is because the regulation of telomerase activity is very complex and many factors are involved in the process from hTERT transcription to telomerase activation, including those involved in the regulation at hTERT post-transcription level such as protein expression, protein phosphorylation/dephosphorylation, and protein-protein interaction, as well as the involvement of other telomerase subunits $(28-32)$. In present study, the expression of hTP1 increased markedly, appearing to be among those other regulators. However, the expression of hTP1 transcription in differentiated cells seems to depend on the differentiation inducer and cell line used $(25,33-35)$. Since hTP1 was reported to play a regulatory function in enzyme activity by truncation from p240 to p230 (35), its role in the differentiation process deserves further elucidation.

A better understanding of the mechanisms of telomerase regulation will provide a basis for further investigation and manipulation of telomerase activity as a potential therapeutic treatment. It is reported that the alternative splicing of hTERT mRNA may have some effect on the regulation of telomerase activity. The only one confirmed variant that can be expressed as the protein and exert telomerase activity is full-length hTERT mRNA (hTERT $\alpha^{+} \beta^{+}$). However, other splicing variants' function in the regulation of telomerase activity is still not clearly known. During the development of fetal kidney, telomerase activity in the kidney was only present at those gestational ages when full-length hTERT mRNA was expressed, with other spliced transcripts continuing to express at later stages of development. It has also been demonstrated that the $\beta$ splicing variant of hTERT continued to maintain a high level of expression after telomerase activity disappeared in fetal kidney tissue samples $(36-38)$. When hTERT $\alpha^{-}$, hTERT $\alpha^{-} \beta^{-}$, and hTERT $\beta^{-}$variants were introduced into normal human fibroblast cells, none of the three alternate splicing variants reconstituted telomerase activity in such transformed cells. Furthermore, hTERT $\alpha^{-}$was found to inhibit telomerase activities in telomerase-positive tumor cells and cause telomere shortening, and even cell death eventually $(20,21)$. The above experimental evidences suggest that the hTERT $\alpha^{-}$variant may exert a negative role in telomerase regulation and the other two splicing variants hTERT $\alpha^{-} \beta^{-}$as well with hTERT $\beta^{-}$may have no positive contribution to telomerase activity. Up to now, there is also no report about the role of hTERT alternative splicing variants on the regulation of telomerase activity in differentiated leukemia cells induced by ATRA. Current investigation showed none of the splicing variants treated with ATRA maintained the same level of expression as untreated cells at both the mRNA and protein levels. The result is consistent with that of Ding's, which showed ATRA down-regulated the expression of hTERT full length mRNA and $\beta^{-}$variant, but did not affect splicing of hTERT (39). According to our results, it was impossible for hTERT $\alpha^{-}$to act as an inhibitor of telomerase activity because it decreased to an undetectable level. As for the other two splicing variants hTERT $\alpha^{-} \beta^{-}$and $\beta^{-}$, if they had a negative role in telomerase activity, their level should increase or remain steady. However, in fact, the supposition was denied by the experiment results in which both of them decreased after ATRA treatment with the fall of telomerase activity. Furthermore, according to several previous references $(20,21)$, these two variants may have no positive role on telomerase activity. So our studies showed that both of them were also not involved in the regulation of telomerase activity during the ATRA-induced differentiation. Additionally, our research directly showed that there was no correlation between the change of splicing variant's distribution and the decrease of telomerase activity. These results suggest that alternative splicing of hTERT mRNA, unlike its role in telomerase regulation during human fetal development, might not contribute to telomerase regulation in differentiated leukemia cells induced by ATRA. 


\section{Acknowledgments}

This work was supported by National Natural Science Foundation of China (No. 30271513). The mouse antihTERT antibody was kindly provided by the Institute of Genetics, Fudan University (Shanghai, China).

\section{References}

1 Greider CW, Blackburn EH. Identification of a specific telomere terminal transferase activity in Tetrahymena extracts. Cell. 1985; 43:405-413.

2 Lingner J, Hughes TR, Shevchenko A, Mann M, Lundblad V, Cech TR. Reverse transcriptase motifs in the catalytic subunit of telomerase. Science. 1997;276:561-567.

3 Hiyama K, Hirai Y, Kyoizumi S, Akiyama M, Hiyama E, Piatyszek MA, et al. Activation of telomerase in human lymphocytes and hematopoietic progenitor cells. J Immunol. 1995;155: 3711-3715.

4 Kim NW, Piatyszek MA, Prowse KR, Harley CB, West MD, Ho $\mathrm{PL}$, et al. Specific association of human telomerase activity with immortal cells and cancer. Science. 1994;266:2011-2015.

5 Morrison SJ, Prowse KR, Ho P, Weissman IL. Telomerase activity in hematopoietic cells is associated with self-renewal potential. Immunity. 1996;5:207-216.

6 Wright WE, Piatyszek MA, Rainey WE, Byrd W, Shay JW. Telomerase activity in human germline and embryonic tissues and cells. Dev Genet. 1996;18:173-179.

7 Counter CM, Gupta J, Harley CB, Leber B, Bacchetti S. Telomerase activity in normal leukocytes and in hematologic malignancies. Blood. 1995;85:2315-2320.

8 Yasumoto S, Kunimura C, Kikuchi K, Tahara H, Ohji H, Yamamoto $\mathrm{H}$, et al. Telomerase activity in normal human epithelial cells. Oncogene. 1996;13:433-439.

9 Bodnar AG, Ouellette M, Frolkis M, Holt SE, Chiu CP, Morin $\mathrm{GB}$, et al. Extension of life-span by introduction of telomerase into normal human cells. Science. 1998;279:349-352.

10 Hahn WC, Counter CM, Lundberg AS, Beijersbergen RL, Brooks MW, Weinberg RA. Creation of human tumour cells with defined genetic elements. Nature. 1999;400:464-468.

11 Sharma HW, Sokoloski JA, Perez JR, Maltese JY, Sartorelli AC, Stein CA, et al. Differentiation of immortal cells inhibits telomerase activity. Proc Natl Acad Sci USA. 1995;92:1234312346.

$12 \mathrm{Xu}$ D, Gruber A, Peterson C, Pisa P. Supression of telomerase activity in HL60 cells after treatment with differentiating agents. Leukemia. 1996;10:1354-1357.

13 Xu D, Gruber A, Bjorkholm M, Peterson C, Pisa P. Suppression of telomerase reverse transcriptase (hTERT) expression in differentiated HL-60 cells: regulatory mechanisms. Br J Cancer. 1999;80:1156-1161.

14 Bestilny LJ, Brown CB, Miura Y, Robertson LD, Riabowol KT. Selective inhibition of telomerase activity during terminal differentiation of immortal cell lines. Cancer Res. 1996;56: 3796-3802.

15 Hansen LA, Sigman CC, Andreola F, Ross SA, Kelloff GJ, De Luca LM. Retinoids in chemoprevention and differentiation therapy. Carcinogenesis. 2000;21:1271-1279.
16 Yamada O, Takanashi M, Ujihara M, Mizoguchi H. Downregulation of telomerase activity is an early event of cellular differentiation without apparent telomeric DNA change. Leuk Res. 1998;22:711-717.

17 Cong YS, Wen J, Bacchetti S. The human telomerase catalytic subunit hTERT: organization of the gene and characterization of the promoter. Hum Mol Genet. 1999;8:137-142.

18 Kilian A, Bowtell DD, Abud HE, Hime GR, Venter DJ, Keese $\mathrm{PK}$, et al. Isolation of a candidate human telomerase catalytic subunit gene, which reveals complex splicing patterns in different cell types. Hum Mol Genet. 1997;6:2011-2019.

19 Ulaner GA, Hu JF, Vu TH, Oruganti H, Giudice LC, Hoffman AR. Regulation of telomerase by alternate splicing of human telomerase reverse transcriptase (hTERT) in normal and neoplastic ovary, endometrium and myometrium. Int $\mathrm{J}$ Cancer. 2000;85:330-335.

20 Colgin LM, Wilkinson C, Englezou A, Kilian A, Robinson MO, Reddel RR. The hTERT alpha splice variant is a dominant negative inhibitor of telomerase activity. Neoplasia. 2000;2: 426-432.

21 Yi X, White DM, Aisner DL, Baur JA, Wright WE, Shay JW. An alternate splicing variant of the human telomerase catalytic subunit inhibits telomerase activity. Neoplasia. 2000;2:433-440.

22 Kim NW, Wu F. Advances in quantification and characterization of telomerase activity by the telomeric repeat amplification protocol (TRAP). Nucleic Acids Res. 1997;25:2595-2597.

23 Said AS, Sun JL, Chen Z, Huang JS, Shen XR, Zhang BS, et al. Cloning, expression of a segment of hTERT gene and detection of telomerase and hTERT by anti-hTERT polyclonal antibody. Acta Biol Exp Sinica. 2000;33:251-255.

24 Xu D, Popov N, Hou M, Wang Q, Bjorkholm M, Gruber A, et al. Switch from Myc/Max to Mad1/Max binding and decrease in histone acetylation at the telomerase reverse transcriptase promoter during differentiation of HL60 cells. Proc Natl Acad Sci USA. 2001;98:3826-3831.

25 Koyanagi Y, Kobayashi D, Yajima T, Asanuma K, Kimura T, Sato $\mathrm{T}$, et al. Telomerase activity is down regulated via decreases in hTERT mRNA but not TEP1 mRNA or hTERC during the differentiation of leukemic cells. Anticancer Res. 2000;20:773-778.

26 Liu WJ, Jiang JF, Xiao D, Ding J. Down-regulation of telomerase activity via protein phosphatase $2 \mathrm{~A}$ activation in salvicineinduced human leukemia HL-60 cell apoptosis. Biochem Pharmacol. 2002;64:1677-1687.

27 Lin Z, Lim S, Viani MA, Sapp M, Lim MS. Down-regulation of telomerase activity in malignant lymphomas by radiation and chemotherapeutic agents. Am J Pathol. 2001;159:711-719.

28 Kang SS, Kwon T, Kwon DY, Do SI. Akt protein kinase enhances human telomerase activity through phosphorylation of telomerase reverse transcriptase subunit. J Biol Chem. 1999;274: 13085-13090.

29 Li H, Zhao LL, Funder JW, Liu JP. Protein phosphatase 2A inhibits nuclear telomerase activity in human breast cancer cells. J Biol Chem. 1997;272:16729-16732.

30 Li H, Cao Y, Berndt MC, Funder JW, Liu JP. Molecular interactions between telomerase and the tumor suppressor protein $\mathrm{p} 53$ in vitro. Oncogene. 1999;18:6785-6794.

31 Smith S, de Lange T. Tankyrase promotes telomere elongation in human cells. Curr Biol. 2000;10:1299-1302.

32 van Steensel B, de Lange T. Control of telomere length by the 
human telomeric protein TRF1. Nature. 1997;385:740-743.

33 Reichman TW, Albanell J, Wang X, Moore MA, Studzinski GP Downregulation of telomerase activity in HL60 cells by differentiating agents is accompanied by increased expression of telomerase-associated protein. J Cell Biochem. 1997;67:1323.

34 Uchida N, Otsuka T, Shigematsu H, Maeda M, Sugio Y, Itoh Y, et al. Differential gene expression of human telomeraseassociated protein hTERT and TEP1 in human hematopoietic cells. Leuk Res. 1999;23:1127-1132.

35 Nakayama J, Saito M, Nakamura H, Matsuura A, Ishikawa F. TLP1: a gene encoding a protein component of mammalian telomerase is a novel member of WD repeats family. Cell. 1997;88:875-884.

36 Ulaner GA, Giudice LC. Developmental regulation of telomerase activity in human fetal tissues during gestation. Mol Hum
Reprod. 1997;3:769-773.

37 Ulaner GA, Hu JF, Vu TH, Giudice LC, Hoffman AR. Telomerase activity in human development is regulated by human telomerase reverse transcriptase (hTERT) transcription and by alternate splicing of hTERT transcripts. Cancer Res. 1998;58: 4168-4172.

38 Ulaner GA, Hu JF, Vu TH, Giudice LC, Hoffman AR. Tissuespecific alternate splicing of human telomerase reverse transcriptase (hTERT) influences telomere lengths during human development. Int J Cancer. 2001;91:644-649.

39 Ding Z, Green AG, Yang X, Chernenko G, Tang SC, Pater A. Retinoic acid inhibits telomerase activity and downregulates expression but does not affect splicing of hTERT: correlation with cell growth rate inhibition in an in vitro cervical carcinogenesis/multidrug-resistance model. Exp Cell Res. 2002;272: 185-191. 